\title{
Stereotypes of Speech as Indicators of The Ethnic Belonging to Russian-Language Writers of Kazakhstan
}

\author{
Shanayev R.U., Dzholdasbekova B.U., Tumanova A.B. \\ Al-Farabi Kazakh National University \\ 050054, Al-Farabi av. 71, Almaty, Kazakhstan
}

\begin{abstract}
Article is devoted to a research of an ethnic stereotype in the fiction of Russian-language writers of Kazakhstan, in particular a stereotype of speech. Article provides short review of scientific sources on this problem. The following tasks were selected: to observe the way the stereotypic scheme of thinking presented in the author's speech or through the ethnic consciousness and worldview in characters' speech. In the fiction the following main features of a stereotype in speech of the Russian-language (Kazakh by nationality) bilingual writer language identity was described: existence of a certain structure; use of proverbs, sayings, metaphors in words and collocations, comparisons.
\end{abstract}

Key words: national (ethnic) stereotype, stereotype of speech, Russian-language writer, perception of the world, worldview

\section{Introductory remarks}

It is known that the concept of "stereotype" was introduced by W. Lippmann in the development of the concept of public opinion (1922). He gives the following definition: a stereotype is a pattern of perception, filtering, interpretation of information in distinction and recognition of the surrounding world, adopted in historical commonality, based on previous social experience. The system of stereotypes is a social reality [1. C. 7]. This definition is initially widely used in sociology and psychology, then - in all scientific studies of a humanitarian nature. And now the term "stereotype" functions freely in the common language [1-14].

X. Putnam was the first to refer to the concept of "stereotype" in its relationship with language. His works "Is Semantics Possible?" (1970) and "Meaning of Value" (1975) served as the basis for further research of stereotypes in the language, which were conducted in Germany, France, Australia, Poland and Russia (where the concept of E. Bartminsky is well known). In the scientific works of X. Putnam, and then in works of E. Bartminsky, this concept has been applied to any entities (objects, phenomena, events, people, animals, plants, etc.) with which a person comes into contact in his cognitive and practical activities and which receive designation in the language [Putnam, 1975; Bartminsky, 2005]. If the stereotype was originally understood as some "subjective" addition to the "objective" image of the subject, and the language stereotype as a connotative (evaluative) addition

C Shanayev R.U., Dzholdasbekova B.U., Tumanova A.B., 2019

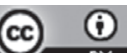

This work is licensed under a Creative Commons Attribution 4.0 International License 
to the lexical meaning of the word (accuracy does not exhaust the German image and the meaning of the German word), reflecting the collective opinion of the corresponding denotate, later, the stereotype was interpreted as an integral "naive theory" of an object (object, person or phenomenon), including not only evaluative (connotative, integral), but also categorical (identifying) signs ("representation of how a X appears, what he does what is he" [13; 14 C. 249]), i.e., in accordance with well understood lexical meaning of words.

Works of foreign and Russian scientists in the field of linguistics, psycholinguistics, ethnopsycholinguistics and intercultural communication, such as D. Katz and K. Braley, O. Kleinberg, H. Triandis and V. Vasiliou, H. Schonfield, L. Edwards; P. Trusov and A.S. Filippov, Yu.A. Sorokin, Yu.E. Prokhorov, N.V. Ufimtseva, E.F. Tarasov, A.A. Zalevskaya, V.V. Krasnykh, V.A. Ryzhkov and others were devoted to stereotype and its specifics.

In further development of this issue and its concretization following scientists' studies were devoted: C.B. Smooth, T.M. Nikolaeva, B.U. Dzholdasbekova, Z.K. Sabitova, O.N. Frolova, E.A. Ivanova, A.B. Pavlovskaya, A.V. Sergeeva, I.P. Sheveleva etc.

In modern times, as a result of globalization and integration barriers between states and nations are blending, the fact that in the sphere of international relations and communication only knowledge of foreign languages is not enough, you need to have a certain degree of competence especially important becomes knowledge of the culture of a given people/country. The most directly related to the process of mastering a new language/new culture in these conditions is the problem of using stereotypes as phenomena that facilitate contacts, and the study of their national and cultural specifics.

\section{Discussion}

\section{The study of the concept of "ethnic stereotype"}

In science, it is established that the stereotype begins to act even before the mind turns on. This imposes a specific imprint on the data that are perceived by our senses even before these data reaches mind. Nothing opposes education or criticism more than stereotype, since it leaves its mark on the actual data at the moment of their perception.

Specialists who study the stereotype, consider it from different positions. In this regard, social stereotypes, communication stereotypes, speech stereotypes and ethnic (national) stereotypes are distinguished [2].

M.Y. Kondratiev considers social stereotype as "a simplified view of an individual, group, process, or other social object that is highly stable. The social stereotype expresses the habitual attitude to a certain object, formed under the influence of living conditions, social environment and previous experience" [3]. I.M. Kuznetsov believes that the specification of a more general concept of "social stereotype" is a concept of "ethnic stereotype". "Ethnic stereotypes are relatively stable ideas about the moral, mental, physical qualities inherent in representatives of various ethnic communities. The content of ethnic stereotypes, as a rule, recorded evaluative opinions about these qualities. In addition, in the content of ethnic stereotypes, there may be prescriptions to action regarding people of a given nationality" [4].

In the Dictionary of Linguistic Terms, T.V. Zherebilo gives the following definition: an ethnic stereotype (ethno-stereotype) is a schematic standardized image of representatives 
of one or another ethnic group, emotionally colored and highly resistant: for example, the Germans are hardworking and prudent [5. P. 675].

By definition of V.N. Telia, stereotypes (as well as standards) are "a kind of constants of the linguistic picture of the world, because through these names that every day domestic view of the world, which is fixed by this language, is interwoven into the conceptual picture" [6. P. 46].

According to Z.K. Sabitova, a stereotype is a judgment that ascribes certain properties in a simplifying, generalizing emotional form to a specific group of persons or, on the contrary, denies them in these properties [7. P. 159]. Based on the definition of W. Lippman that "stereotypes are ordered, schematic, determined by the culture of "pictures of the world" in a person's head, which save his efforts in perceiving complex social objects and protect his values and rights" [1. P. 7], the scientist concludes: "It means, the stereotype has two components: the determinism of culture and the ability to be a means of saving effort (examples of stereotypical image in each culture: a turtle, rooster, ram, beetle, etc.)" [7. P. 160-161]. We agree with the opinion of the researcher that there are stereotypical ideas about the whole nation, which apply to each of its representatives, for example, German orderliness, Russian perhaps, Chinese ceremonies, Italian temper, French chivalry, and etc. Most of the jokes about the national character are based on stereotypes, and the objects of assessment can be not only character traits, behavioral patterns, but also traditions and customs (for example, making a visiting) [7. P. 161].

O.N. Frolova proposes to consider the stereotype as a standard pattern of thinking, actions and attitudes of the individual to the world and his other representatives, filled with different content depending on the individual's belonging to a certain social, ethnic or cultural community [8. P. 5].

Summarizing the different points of view on this problem, we draw some conclusions:

1) National culture and language (as an indicator of an ethnos and as the main component) are connected through the consciousness of a linguistic personality. In this connection, stereotype plays an important role, which is one of the main national-specific components of the culture of a given nation.

2) If we consider culture as the activity of people in reproducing the characteristics of social being, then it is clear that within the framework of culture certain types of stereotypes can be distinguished, such as customs, rites, traditions, rituals, speech, behavior, etc.

3) Stereotypes, being a definite means of transmitting social experience of a particular ethnos, possess stability and reproducibility (passing from generation to generation); in this paper, the definitions of national and ethnic to the term "stereotype" are used interchangeably.

4) A stereotype is a phenomenon of culture and, as a result, requires careful study of its signs and functions, mechanisms of its formation and distribution in the form of language models of the world ("world pictures").

It is known that the linguistic models of the world and their formation do not lead to the formation of special pictures of the world, but various ways of reflecting the unified world of reality are presented. Yu.E. Prokhorov, speaking of the reflection of reality in language, conditionally identifies three levels: 1 ) a description of the real picture of the world, which lies at the basis of the entire human world perception and world view; 2) revealing the specifics of the reflection of a certain ethnos of the real picture of the 
world, which is associated with the organization of the worldview of this ethnic group; 3 ) a description of the features of linguistic expression of the specifics of the reflection of the model of the world that is inherent in this ethnos, which includes both knowledge of linguistic units and their structural organizations, and the ability to use them in the communicative behavior that is normative for a given linguocultural community [9. P. 52]. In accordance with these levels, general, particular, and linguistic stereotypes are distinguished. National cultural specificity is more clearly manifested in stereotypes of the second and third types [8]. Further, we will dwell in more detail on their characteristics, and for illustration we will give examples from the artistic works of Russian-speaking writers of Kazakhstan (in our case, Kazakhs by nationality): A. Alimzhanov, S. Sanbaeva, B. Dzhandarbekova, A. Zhaksylykova.

\section{Research results}

It is well known that the ability to express beautifully, figuratively, is a national feature of the Kazakh nation, which was formed as a result of the reflection of a certain, standard pattern of thinking that has developed over a long period of life of the nomadic people. And this allows us to define this specific feature of speech activity as a stereotype of speech of a representative of an ethnos. So, this is convincingly written by B.U. Dzholdasbekova: "Nikolai Anov in "Wings of Song" shows in what difficult and tense conditions the new art of the nation was born, whose interests it expressed, and creates images of non-national heroes who absorbed the best features of the Kazakh people. He reveals one of the national peculiarities of the Kazakhs - their traditional respect for the word and song, love and ability to improvise, awareness of oral and song creation as a great social aesthetic power". [10. P. 146]. The scientist describes how the famous Kazakhstani (native St. Petersburg resident) writer Nikolai Ivanovich Ivanov (pseudonym - Anov), through internal monologues and improperly direct speech, depicts the rich inner world of a foreign hero. Akyn is spontaneous and emotional in expressing its feelings - both joyful and sorrowful. This is a whole nature that does not tolerate lies, hypocrisy, double-headed and halfheartedness. Further, it is justly argued that in the course of creating the foreign character of the akyn Musa Bazanov (Isa Baizakov), a real image of a Kazakh with real speech features is created: "His speech is full of proverbs and sayings, emotional, different artistic imagery - all this enriches the meaning and adorns his songs and statements" [10. P. 148]. In connection with the above, it is appropriate to quote the researcher of Russian literature in Kazakhstan I. Gabdirov that the image of Musa is "the distinctive national character ... one of the most prominent personalities depicted by Anov. The talent of the Kazakh people, his love for the song art are embodied in the character of the hero ... Anov recreated the national character in all its freshness, originality and complexity" [11. P. 88].

Our research has shown that such a stereotype of speech is vividly and uniquely presented in the artistic text of Russian-speaking writers of Kazakhstan. The originality is due to the special status of Russian-language literature, which was formed at the junction of two cultures: Russian and Kazakh. The works are created in Russian, but according to the way of reflecting reality, the national view is "visible" in them: ethnic worldview and world representation. As a result, the fiction text presents not a purely Russian and not a purely Kazakh language picture of the world, but some third one that we called contaminated [12. P. 7]. 
Let us present some of the results of our observations. The stereotype of the speech of the representative of the Kazakh people in the Russian artistic text has its own characteristics:

1) the presence of a stereotype of speech is noted in the author's own speech, in the speech of the narrator, in the speech of the characters and in improperly direct speech, which directly indicates the creator of the text - the Russian-speaking Kazakh writer;

2) skillful and stylistically motivated use of proverbs and sayings, catch phrase and phrases, etc. accompanied by sustainable structures such as aksakals/elders/wise/old men speak, Kazakhs speak, people say, etc.;

3) this stereotype of speech is presented in several forms: a) by means of a direct translation of the Kazakh proverb/saying; b) using the analogy of proverbs/sayings introduced with Russian equivalents, etc.; c) the use of figurative words and comparisons characteristic of the life and culture of the nomadic people; d) formation of tropes based on nominations of animals and birds of the steppe space [12].

The analysis has shown that the characters' speech is saturated with various folk sayings and sayings, especially the speech of aksakals, elders, and respected batyrs. For example:

"After all, words are like arrows. The Kazakhs say: "A blow of a stick will break only the skin, a sharp word will pierce not only the heart, but also the bones" (Alimzhanov. Arrow of Makhambet, 1979. P. 79).

In the following excerpt, in the speech of Isatai (part of the dialogue between the leaders of Isatai and Makhambet, the latter, as well as sarbazs', forced the expectation of battle out of balance), with the help of the construction, Kazakhs say that a translation of the Kazakh saying is introduced. And it is no coincidence - with this method we see an ethnic worldview, a national psychology. Comparison:

"... A week has passed. There are still three days left. Kazakhs say: who languished, waiting forty days, will survive the forty first...” (Alimzhanov. Arrow of Makhambet, 1979. P. 134).

Vivid examples of contamination (mutual influence) of the Kazakh and Russian cultures, in our opinion, seem to be a peculiar use of proverbs and sayings: using a roll of transmitted meanings, their use by analogy with Russian equivalents, when conveying meaning adequate to the Russian version, but filled with regionalism. Let us compare the proverbs/sayings used by the Russian-speaking writer:

"And when Haji becomes even wiser", Adaybek said quietly but distinctly, without looking at anyone, - the pots will probably also know these words: "A foolish quarrel, coming to put up, smart, coming by war, will offer peace...” (Sanbayev. Only one road, 1974. P. 317);

"I also speak openly: I will not stand with you against the queen. Better a living sparrow than a dead falcon!' (Dzhandarbekov. Tomiris, 1982. P. 60);

"Fate again laid an iron hand on me. As the saying goes, a marsh owl will never become a falcon" (Zhaksylykov. White Argali, 1987. P. 76)

with Russian proverbs, such as "A clever man seeks a way to reconciliation, a fool is a reason for a quarrel", "Better a bird in the hand than a crane in the sky", etc.

The main type of activity of nomadic people - cattle breeding and the fact that there is no guarantee of security either from the side of another person or from the forces of 
nature, in a veiled form is mentioned, for example, in the fragment of the speech of the main character of the novel Adaibek:

"No wonder my grandfather said: "Mine is what I ate yesterday; what I drive in front of me today is God's” (Sanbayev. Only one road, 1974. P. 313).

It should be noted that also in the author's speech, ethnic stereotypes are widely introduced in the form of reflection, conclusion, advice on any subject or conclusions dictated by practical activities of the nomadic nation. Comparison:

"If you want to have wool, do not take it off with the skin", said Tomiris" (Dzhandarbekov. Tomiris, 1982. P. 80).

In addition, in the author's own speech, in the author's maxims, very vivid, deeply philosophical thoughts, characteristic of the national world outlook, are introduced. For example:

"There is no worse penalty for a parent than to see his child in misfortune" (Zhaksylykov. Bely argali, 1987. P. 83);

"If the gods punish a person, they take away his mind"; "But if you're not lucky, then the dog will bite you on a camel” (Dzhandarbekov. Tomiris, 1987. P. 38; 44).

Next, we will focus on another feature of the stereotype of speech - the speech of the characters, which is a symbolic reflection of the national consciousness and worldview. It is widely used figurative words and comparisons, known and understood by each of the representatives of the nomadic people (and this is their stereotype!). We have established that it is possible to distinguish a circle of ethnic stereotypes in the form of stable supporting words for the formation of tropes - these are nominations of animals and birds of the steppe space: gazelle, jackal, sheep, wolf, golden eagle, etc. So, in a fragment - in a conversation with villagers, the character of the novel Nurzhan speaks about the need to unite representatives of different zhuzes into which the Kazakh people are divided. For example:

"When trouble comes, even a wolf does not pick up a sheep - they unite to survive... I am not a wolf, and you are not a harmless sheep, Adaybek. The time has come when we should forget about past quarrels and think about unity" (Sanbayev. Only one road, 1974. P. 313);

"We, like a flock of frightened sheep, running away along the steppe from the wolf pack of the Dzungars" (Alimzhanov. Arrow of Makhambet, 1983. P. 9);

"Oh, curse you khans, sultans, like jackals, tearing apart their land, their people..." (Alimzhanov. Arrow Makhambet, 1979. P. 10).

A special place among the reference figurative operators occupy the nomination of domestic animals - the horse, the camel (there are enough works in the works of art about the functioning of the lexeme horse). Our studies of the textual semantics of the lexical unit camel allow us to speak about the ethnic specificity of the figurative meanings associated with this word. A camel in the mind of a Kazakh is an awkward animal. The clumsiness of an animal is "transferred" to a person just as in the Russian language consciousness the bear's clumsiness is "transferred" to a person. So metaphorical epithets arise, compare:

"With his camel's gait, he (Zhakyp - our refinement) walked around the corral, adjusting the leaning posts" (Alimzhanov. Arrow of Makhambet, 1979. P. 83); 
"Why are you staring at me, old camel. Help the jigits deliver this handsome man to the tent of Khan! - the vizier ordered ..." (Alimzhanov. Arrow of Makhambet, 1979. P. 85);

"Now I remember my aul, my first stop, like that old camel that the female worries ..." (Alimzhanov. Teacher's Return, 1983. P. 101).

The stereotype of comparison in the speech of characters often includes a detailed object, and the detailing is carried out with the help of Kazakhisms. For example:

"My two sons are buried in their native land, and the third is killed in the zindan of the Khiva Khan. And I, like a crazy bura (female camel), circling around Mangystau and Ust-Urt around dear graves"(Alimzhanov. Arrow of Makhambet, 1979. P. 118).

The detailed object "old distraught bura (camel)" includes a nationally specific semantic component. The grief of a man who has lost all his sons is unlimited, unbearably painful. It is not by chance that this old man is associated with a bura - a camel.

So, the above results of the study, in our opinion, due to the national culture, national consciousness, life, location, type of work, etc., clearly reflect the features of the ethnic stereotype of world perception and world view.

\section{Conclusions}

The conducted study allows us to draw the following conclusions:

- National (ethnic) stereotypes are completely naturally and justifiably represented in the artistic works of Russian-speaking writers of Kazakhstan. Their widespread use in the author's narration and the speech of the characters contributes to the "revitalization" of the speech of the native speaker; it is given a unconstrained, natural character. In addition, in this formalization of the stereotypical speech of a Kazakh, in our opinion, the features of the national code of the creator are "visible".

- These stereotypes are vivid representatives of the ethnic worldview and world representation, due to national consciousness, national character, geographical place of residence, social environment, the specifics of work, etc.

- In modern conditions of a person's / society's life, the problem of educating a person, the formation of not only communicative competence, but also general cultural competence, becomes especially important. Therefore, the formation of the ethnocultural identity of a linguistic personality is associated not only with the development of linguistic competence in it, but also with the formation and improvement of the ability to navigate in a broad ethnocultural context. In this regard, it is imperative to inculcate and develop the skills of reading and perception of fiction, historical chronicles, works of oral folk art, etc. in the humanities class. A good example to achieve these goals and objectives is to use the texts of literature written Russian language in Kazakhstan.

\section{References}

1. Lippman, W. 1922. Public Opinion - New York: Hartcourt, Brace and Co. Print.

2. Yazyikovoe soznanie: stereotipyi i tvorchestvo [Language Consciousness: Stereotypes and Creativity]. Editor-in-Chief Ufimtseva N.V. Moscow: IYaZ. 1988. Print. (In Russ.)

3. Kondratev, M.Yu. Sotsialnyiy stereotip. Sotsialnaya psihologiya [Social stereotype. Social psychology]. [Electronic resource]. Access mode: http: www.slovari.yandex.ruI dictIpsychlex4I articleIPS4Ips4-0312.html Print. (In Russ.) 
4. Kuznetsov, I.M. Etnicheskiy stereotip. Sotsialnaya psihologiya [Ethnic stereotype. Social psychology]. Dictionary [Electronic resource]. Access mode: http:www.slovari.yandex.ruIdictI psychlex4IarticleIPS4Ips4-0313.html

5. Zherebilo, T.V. 2010. Slovar lingvisticheskih terminov [Dictionary of Linguistic Terms: Edition 5, correction and addition]. Nazran: "Pilgrim" Publishing House. Print. (In Russ.)

6. Telia, V.N. 1986. Konnotativnyiy aspect semantiki nominativnyih edinits [Connotative Aspect of Semantics of Nominal Units]. Moscow: Nauka. Print. (In Russ.)

7. Sabitova, Z.K. 2013. Lingvokulturologiya [Linguoculturology]. Textbook. Moscow: Flinta. Print. (In Russ.)

8. Frolova, O.N. 2009. Natsionalno-kulturnaya spetsifika stereotipa [National-cultural Specificity of the Stereotype]. Abstract of the thesis for the degree of Candidate of sciences. Moscow. Print. (In Russ.)

9. Prokhorov, Y.E. Natsionalnyie sotsiokulturnyie stereotypy I rechevogo obscheniya i ih rol' v obucheni irusskomu yazyiku inostrantsev [National Socio-cultural Stereotypes of Speech Communication and their Role in Teaching the Russian language to Foreigners] [Text]. Y.E. Prokhorov. M.: LKI Publishing House, 1996. 357 p.

10. Dzholdasbekova, B.U. 2008. "Innonatsionalnyiy harakter v proze N. Anova (sredstva sozdaniya obraza geroya «Kryilya pesni»)" [Foreign Character in prose of N. Anov (means of creation of an image of the hero "Wings of a song"] in Russian literature of Kazakhstan. Monograph. Almaty, 2008. $278 \mathrm{p}$.

11. Gabdirov, I. 1970. Russkie sovetskie pisateli I Kazahstan [Russian Soviet writers and Kazakhstan]. Moscow: Nauka. Print. (In Russ.)

12. Tumanova, A.B. 2010. Kontaminirovannaya yazyikovaya kartina mira v hudozhestvennom diskurse pisatelya-bilingva [Contaminated Language Picture of the World in the Artistic Discourse of the Writer-bilingual]. Monograph. Almaty. Print. (In Russ.)

13. Putnam, H. 1970. "Is Semantics Possible?" in Mind, Laguage and Reality. Cambrige, 1970. P. $139-152$.

14. Putnam, H. 1970. The meaning of "meaning" in Mind, Laguage and Reality. Cambrige, 1975. P. 215-221.

\section{Article history:}

Received: 07.05.2019

Accepted: 07.08.2019

Moderator: U.M. Baktikireeva

\section{Conflict of interests: none}

\section{For citation:}

Shanayev, R.U., B.U. Dzholdasbekova, and Tumanova A.B. 2019. "Stereotypes of Speech as Indicators of the Ethnic Belonging to Russian-Language Writers of Kazakhstan". Polylinguality and Transcultural Practices, 16 (3), 366-374. DOI 10.22363/2618-897X-2019-16-3-366-374

\section{Bio Note:}

Ruslanbek U. Shanaev is a Postgraduate student at the Department of Russian and Foreign Literature RUDN University, PhD PhD student at the Department of Russian Philology and World Literature, Al-Farabi Kazakh National University. E-mail: rus.shanaeff@gmail.com

Bayan U. Dzholdasbekova is a Doctor of Philology, Professor, the Head of the Department of Russian Philology and World Literature at the Al-Farabi Kazakh National University. E-mail: dzholdasbekova.baiyan@kaznu.kz

Ainagul B. Tumanova is a Doctor of Philology, Professor of the Department of Russian Philology and World Literature, Al-Farabi Kazakh National University. E-mail: a.tumanova@inbox.ru 


\title{
Стереотипы речи как индикаторы этнической принадлежности к русскоязычным писателям Казахстана
}

\author{
Р.У. Шанаев, Б.У. Джолдасбекова, А.Б. Туманова \\ Казахский национальный университет им. Аль-Фараби \\ 050054, Проспект Аль-Фараби, 71, Алматы, Казахстан
}

Работа посвящена исследованию этнического стереотипа в художественной литературе русскоязычных писателей Казахстана, в частности стереотипа речи. Статья содержит краткий обзор научных источников по данной проблеме. Задачей исследования было выяснить, как стереотипная схема мышления представлена в речи автора или через этническое сознание и мировоззрение в речи персонажей. В художественной литературе были описаны следующие основные черты стереотипа в речи русскоязычной (казахской по национальности) языковой идентичности двуязычного писателя: наличие определенной структуры; использование пословиц, поговорок, метафор в словах и словосочетаниях, сравнения.

Ключевые слова: национальный (этнический) стереотип, стереотип речи, русскоязычный писатель, восприятие мира, мировоззрение

\section{История статьи:}

Поступила в редакцию: 07.05.2019

Принята к печати: 07.08.2019

Модератор: У.М. Бахтикиреева

Конфликт интересов: отсутствует

\section{Для цитирования:}

Шанаев Р.У., Джолдасбекова Б.У., Туманова А.Б. Стереотипы речи как индикаторы этнической принадлежности к русскоязычным писателям Казахстана // Полилингвиальность и транскультурные практики. 2019. Т. 16. № 3. С. 366-374. DOI 10.22363/2618-897X-201916-3-366-374

\section{Сведения об авторах:}

Шанаев Русланбек Улугбекович - аспирант кафедры русской и зарубежной литературы РУДН, PhD докторант кафедры русской филологии и мировой литературы КазНУ им. аль-Фараби. E-mail: rus.shanaeff@gmail.com

Джолдасбекова Баян Умирбековна - доктор филологических наук, профессор кафедры русской филологиии и мирвой литературы КазНУ им. аль-Фараби. E-mail: dzholdasbekova. baiyan@kaznu.kz

Туманова Айнагуль Бектасовна - доктор филологических наук, профессор кафедры русской филологии и мировой литературы КазНУ им. аль-Фараби. E-mail: a.tumanova @inbox.ru 